\title{
IL1A wt Allele
}

National Cancer Institute

\section{Source}

National Cancer Institute. IL1A wt Allele. NCI Thesaurus. Code C50928.

Human IL1A wild-type allele is located within $2 q 14$ and is approximately $11 \mathrm{~kb}$ in length.

This allele, which encodes interleukin-1 alpha protein, plays a role in various immune responses, inflammatory processes and hematopoiesis. 